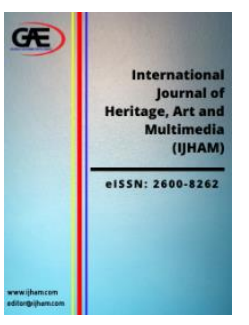

\author{
INTERNATIONAL JOURNAL OF \\ HERITAGE, ART AND MULTIMEDIA \\ (IJHAM) \\ WwW.ijham.com
}

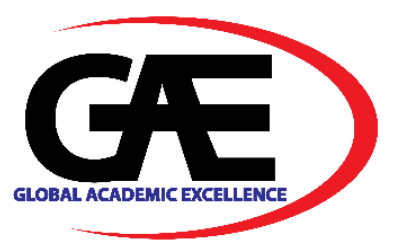

\title{
DISCOURSE ON SOURCES, INTERPRETATION AND WRITING OF HISTORY IN NIGERIA TODAY
}

\author{
Joseph Bonglo Kingsley ${ }^{1 *}$, Suffian Mansor ${ }^{2}$, Azlizan Mat Enh ${ }^{3}$ \\ 1 Faculty of Social Sciences and Humanities, Universiti Kebangsaan Malaysia (UKM) \\ Email: kingsleyj67@gmail.com \\ 2 Faculty of Social Sciences and Humanities, Universiti Kebangsaan Malaysia (UKM) \\ Email: smansor@ukm.edu.my \\ 3 Faculty of Social Sciences and Humanities, Universiti Kebangsaan Malaysia (UKM) \\ Email: azlizan@ukm.edu.my \\ * Corresponding Author
}

\section{Article Info:}

\section{Article history:}

Received date: 15.11 .2021

Revised date: 17.12. 2021

Accepted date: 20.12.2021

Published date: 24.12.2021

\section{To cite this document:}

Kingsley, J. B., Mansor, S., \& Mat Enh, A. (2021). Discourse On Sources, Interpretation And Writing Of History In Nigeria Today. International Journal of Heritage, Art and Multimedia, 4 (15), 89-99.

DOI: $10.35631 /$ IJHAM.415008.

This work is licensed under CC BY 4.0

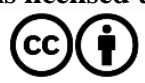

\begin{abstract}
:
The place of sources and interpretation in historical discipline is indeed a crucial and significant one. As important as the vine or tape roots are to the survival of any plant so also is sources and interpretation to historical scholarship. This paper focuses on sources of history and the role of interpretation and writing of history in Nigeria today. The paper analyzed the various sources of history and the role of interpretation and writing of history in Nigeria. For the sources of history and interpretation in the writing of history has a direct effect on the nature, type and quality of history obtained in Nigeria. The paper identified and discusses the various sources for the writing or reconstruction of Nigerian history. Furthermore, it also looks at the role of interpretation and historical writing in Nigeria by examining the critical role and responsibility on the historian in reconstructing or writing Nigerian history. It equally, examines the impact of sources and interpretation on the writing of history in Nigeria. The paper adopts the historical-cum-library method of research which is based on secondary sources and involved descriptive collation and analysis of historical data to come out with its findings. In conclusion, the paper revealed that the sources for the writing and reconstruction of history in Nigeria are divided in to primary and secondary sources. While the primary sources comprised of oral, archaeological, linguistics, ethnographic, anthropology and geography, the secondary included written sources such as nsibidi, Arabic script, Roman script and record of British colonial administrators. Moreover, it also uncovered that the historian was the sole determinant of historical facts and interpretation in the writing of history in Nigeria and that this has impact on the development of historical scholarship in Nigeria.
\end{abstract}


Keywords:

Historical Sources, Interpretation, Reconstruction, Writing, History, Historian, Nigeria

\section{Introduction}

It is important to state here that historical scholarship is not only unique but deeply characterized by lay down rudiments and procedures for a historian to apply as a professional.

Some of these stages have been rightly captured by Carl Becker (1955), in his statement that: "...the historian is concerned with events, acts, thoughts, emotions that have Forever vanished as actual occurrences... He can deal with them because these vanished realities give place to pale reflections, and palpable images or ideas of themselves, and these pale reflections, and palpable images which cannot be touched or handled are all that is left of the actual occurrence. These are therefore what the historian deals with. These are his materials". He has to be satisfied with these, for the very good reason that he has nothing else"

The above statement identifies three key elements which are very indispensable to a historian. The first essential element or tool is the "facts" referred to as "his materials". This means that facts are the materials of the historian. The second important element is the "interpretation" captured in the description "He can deal with them." This could be rightly put as the historian can properly interpret his facts. Meanwhile, the third element is the task of "writing" expressed as "...the historian is concerned with events, acts, thoughts, emotions...". This implies that the historian is interested in writing about events or ocasions, acts or deeds, thouhts or reasonings and emotions or feelings etc. These are the three critical stages that produces a historical document or work. However, it is important to admit that the role of a historian is immensely overwhelming for all the elements or tools depend on him. In other words, the historian is the fulcrum to produce a historical document or work.

This article analyzed the various sources of history and the role of interpretation and writing of history in Nigeria. The purpose is to examine whether based on the approach adopted by Nigerian historians, this has actually had significant impact on the development of historical scholarship in Nigeria. The methodology adopted by this study is the historical-cum-library method of research which is based on the use of secondary sources of data and involves a descriptive collation and analysis of historical data. In the light of the foregoing, this paper is divided into the following: - introduction, literature review, type of sources for history in Nigeria, interpretation of facts in the writing of history in Nigeria, the impact of interpretation and writing of history in Nigeria, and conclusion.

\section{Literature Review}

\section{Conceptual Clarification}

History as a discipline has been largely misconstrued by so many people despite the fact that all phenomenon has a history. Some of the reasons according to Joseph et al(2015), why it is so is because majority are naïve, fearful of the subject, uninterested in the discipline and often 
Volume 4 Issue 15 (December 2021) PP. 89-99 DOI 10.35631/IJHAM.415008

forget that one of the major purpose of history is to supply information which addresses in a unique manner the following fundamental questions: what, how, when, who and why? It is important to note that more often those involved in such phenomena or event hardly pay attention to address these significant questions during their involvement or life time. And even if they do it may not be exhaustive for each generation see phenomenon and events in different light from others. At the end the upcoming generations are faced with the task to get systematic answers which connect the past to the present and the future. However, where an individual or a generation/nation fails to get answers to the above questions such is doom for destruction due to the disconnect.

Nevertheless, the onus to fixed the disconnect solely lies with the historical discipline. This is where the required training and skills are acquired by the historiographers whose duty it is to fashion out the solution or remedy and clear away ignorance and doubt. This is why Varvar (2010), rightly observed that history as a body of knowledge undoubtedly has certain characteristics that put it apart from other forms of knowledge. He further argued that history has some form of logic, methods and perspective which is peculiar to it. How then does a historian go about solving the problem of disconnect as his major task?

The evolution in historical scholarship has transformed it from being a merely narrative to an analytical and scientific discipline. However, this approach has led to the introduction of methodology as a core course which do not only address methodological and historiographical issues but has proven to be a sure tool for the training of historiographers on how to handle various issues and aspects in the historical discipline (Harbst 1968). The would-be historiographers are taught how to identify the sources to use in a historical construction or reconstruction and also how to skilfully wielder challenges associated with them. They are also made to know the strength and weakness of each source (Suleiman 2015). Furthermore, Obiegbu (1997), added that they are shown the guiding roles in the selection of sources and ways to handle difficult and challenging task in the course of carrying out their work. Therefore, with the above being bore in mind a historiographer goes on to get his materials known as the facts and then carry out his historical construction or reconstruction being a specialist in his own craft and profession which undoubtedly has contributed immensely to human development and civilisation holistically.

\section{Type of Sources for the Writing of History in Nigeria}

According to Hassan et al (2015), the sources available for the writing of history in Nigeria can be categorize in to three namely, primary, secondary and tertiary. However, it should be noted that the categorization is usually based on the closeness or remoteness of the information they bear to the subject of study. For example, an eyewitness's account of an event is a primary source, while an information received from an individual who did not witness the event in question himself but got to know about it through another who witnessed it is a secondary source. For the tertiary source, this has to do with the medium of information that is remotely connected to the subject being studied. Moreover, some of the primary sources used in the study of history in Nigeria and Africa include: - oral evidence, archaeological, linguistics, ethnographical, anthropological and geographical sources. 


\section{Primary Sources}

\section{Oral Evidence}

This type of source provides the historian with information stored in the human brain and transmitted by words of mouth or in spoken form. Hassan et al (2015), stated that this consist of present generation reports by people who either witnessed the events themselves or got their information from those who were eyewitnesses. Similarly, Joseph et al (2015), also remarked that oral sources are pieces of historical information transmitted by words of mouth from person to person in a formal or informal way. According to them this source is prevalent mostly in pre-literate societies and known as oral evidence. Contributing to the discourse Falola et al (1999), asserted that oral traditions is the account of the past of people passed on orally from one generation to another up to the present and that traditions of origin of Nigerian people are, thus, oral accounts about the beginnings of various ethnic groups usually given by each of them from generation to generation and from time immemorial. Similarly, Valerie, (1985), interestingly captured oral history as the recording of personal testimony delivered in oral form. Furthermore, Stevens Jr. (1978), defines and identified the role played by various forms of oral traditions. The four broad forms comprised of myths, legends, songs and popular histories.

(I)Myth is a derivation from Greek word mythos meaning the branch of knowledge which is indisputable and not subject to rational argument. This value is placed on it by culture for it deals with fundamental realities and explains the origin of things and why things happen in the way they do as well as establish the standard for human behavior in the society. Therefore, he concluded that myths are more reliable to the historian for the reconstruction of the past.

(II) Legends also constituted another type of historical narrative and speaks of the times after the cultural founders might have departed their earthly lives leaving the actual running of the society in human control. This source derived it authentication through their association with personages, events, or places which might be supported by other traditions, the details of the events described are of questionable historical veracity. However, the role of this source is that it deals with real personages and places, but unlike myths lacks divine sanction and is open to public reference and rational questioning.

(III) Songs are equally, another important form of oral traditions which are vital in the reconstruction of Nigerian history. Oladejo (2014) pointed out that songs were used to preserve memories of battle, economic break through and celebration of festivals. They comprised of poetry, epic, chart fan of verses and so on. They are useful records of the times for better understanding of historical events. Since the composers of songs are free to include statement of social criticism, they are helpful in reconstructing fragmentary pictures of social conditions of the time. He said that this type of source make history to be more lively and vital.

(IV) Popular histories are also known as oral traditions. They are partly. derived from myths, legends, songs and current events. In other words, popularly histories are a combination from other forms of oral sources identified above. The role of popular histories in the reconstruction of Nigerian history is that they reflect changing values and perceptions in the social process and society.

However, it is important to note that oral traditions sources is more abundant and also basic for the reconstructionof Nigerian and African history in general (Curtin, 1981). This has served as 
Volume 4 Issue 15 (December 2021) PP. 89-99 DOI 10.35631/IJHAM.415008

a vital source to exhume the history of Nigeria to a very large extend. Similarly, Dibia and Nwosu (2014) also admits the importance of oral tradition by disclosing that oral tradition was the only source being used for the re-construction of the history of Igboland since, it did not have written and formal sources. It is also the reliance on oral traditions that debunk the Eurocentric view upheld by European scholars like Hugh T. Roper and Hegel that Africa had no history but only the history of European activities. In addition Ibrahim (2009) however declared that it was the Africanist effort in using oral tradition that made it possible for much to be known today about Nigeria and Africa in general in the $20^{\text {th }}$ and $21^{\text {st }}$ centuries.

\section{Archaeology Sources}

This source consists of the relics of material culture created or used by man. Others include artifacts of all sorts, including remain of buildings, evidence of archaic industrial processes, living places, bones of domesticated animals, datable deposits in which pottery, grindstones and human burials have been found (Falola, et al. 1999). Some of the objects form part of the natural environment such as impressions made on the rock surfaces, rockslides, rock shelters, cave paintings or sculptures on stones or rocks. However, it is important to note that the study and interpretation of this remains has revealed very useful information about the past of man in Nigeria, particularly the early human settlements, domestication of plants and animals, the beginning of agriculture, trading activities, relationship between different communities and social stratification in any given society (Andah and Okpoko, 1979). That is why Falola et al. (1999), further asserted that in the last fifty years, significant progress has been made in finding out about the Nigerian past through archaeological sources. He also added that archaeological discoveries were made throughout the entire country, particularly in places where excavations are carried out like in Kursakata, Daima and Shilma in Borno State, Birnin Kudu in Kano State, Kaura Namoda in Sokoto State, the Nok culture in Plateau and Kaduna States, Iwo Eleru, Ilesa and Ife in Oyo State, the Igbo Ukwu in Anambra State and the Ewaoma in River State. Meanwhile, the study of the objects found in these places has shade much light about Nigeria's past dating back to about three thousand years in some places. Therefore, looking at its significant role, archaeology remains a durablesource for the writing and reconstruction of history in Nigeria.

\section{Linguistic Sources}

Furthermore, linguistic materials essentially derived from the study of the meaning of words such as names of places and people, as well as those relating to chronology constituted a source of history (Falola et al. 1999). Since speech or language is part of what gives every human group its identity and shapes the past, this means that historical narratives and works are contents and forms of thought, which are usually produced through the medium of language or speech. Hassan et al. (2015), also remarked that linguistics goes beyond the tool of communication to include the medium for realizing the history of man and civilization.Supporting this view Atando, stated that language is taken as the determinant factor in considering ethnic group identity because it is the means of communication, lacking which corporate existence and separate identity of an ethnic group becomes impossible. Furthermore, Falola et.al. (1999), pointed out that the important type of historical information from linguistic source should include information about common origins of people who today lead separate or distinct existence and of the time that has lapsed since the separation of once united peoples. Similarly, inferences about the location of homeland from which groups of peoples with common origins 
Volume 4 Issue 15 (December 2021) PP. 89-99 DOI 10.35631/IJHAM.415008

initially dispersed and of the directions of their migration (Armstrong, 1960). He added that from the perspective of Nigerian history, linguistic materials could be regarded as superior to both oral and written sources for it is the only source that can show how each of the indigenous groups had come to occupy their present homelands before the dawn of history, that is, before oral traditions and written records.

\section{Ethnographic Sources}

The ethnographic materials play a vital role as a source in the history of Nigeria. It embraced a wide range of data derived from the daily life, customs, beliefs, and various practices of communities (Falola et al 1999). Essentially, it focused on all the various kinds of institutions such as social, political, economic and cultural branches within the Nigerian communities that may be useful to the historian for the reconstruction of the past. Hassn et al (2015), identified some of the ethnographic materials found in research centres, libraries and archives in Nigeria that were compiled by colonial anthropologist and administrators. A good example is an account documented by C. K. Meek titled A Sudanese Kingdom.

\section{Geographical Sources}

This according to Falola e tal. (1999), comprised of sources related to the environment such as topographical, geomophological, climatological, palaeoclimatological data. It also includes all the materials relating to the physical environment of human activity. The wide range of materials here include: - from reconstruction of conditions of the last pluvial period and the desiccation of the Sahara, to the 19th Century description of the countries by European travelers, to the 20th Century geographical survey. This data provides useful historical information that can assist the historian to reconstruct the past immensely.

\section{Secondary Sources}

The written sources of history in Nigeria are derived from all official and legal documents, diaries, letters, newspapers, industrial and commercial records, inscriptions on stones, pottery, bones, metals, maps and diagrams (Falola et al. 1999). However, there are three types of written sources.

(A) The first is nsibidi which is a system of written communication that was used majorly among the Ibibio ethnic nationality. Similarly, written sources also existed among ethnic groups such as the Nupe, Edo and in the Aro area but has not been used by historians possibly for the perception that these traditional sources were restricted to single groups, the secret society within groups or produced on perishable objects like wood, bark, calabash and ivory. Unfortunately, these sources were destroyed by wars and the penetration of Islam and Christianity.

(B) Another written source identified by Falola et al. (1999), is the Arabic sources. The advent of Islam in to the Nigeria area notably Borno and Hausaland resulted in the introduction of Arabic scripts or records dating back to the $10^{\text {th }}$ Century. Scholars continued in the practiced up to the $19^{\text {th }}$ Century, during the period of the Jihad of Usman dan Fodio. Leaders of the Jihad wrote extensively on their activities, and this has been of tremendous help to historians. Similarly, large collection of historical sources written in Arabic are found Ahmadu BelloUniersity, Zaria, Arewa House Kaduna, National Archives, Kaduna and the University of Ibadan. Some are also found at the Jos Museum, Maiduguri Museum, Sokoto Museum, Kano and Katsina Museums. 
Volume 4 Issue 15 (December 2021) PP. 89-99 DOI 10.35631/IJHAM.415008

(C) The second category of written sources of history in Nigeria is the Roman script. The script was introduced into Nigeria through the coastal area in the $15^{\text {th }}$ Century, when Europeans travelers, traders, missionaries and other agents that penetrated the interior or travelled across the Sahara Desert to the Nigeria area. Among these include Barth and Clappertonwho wrote extensively about different aspects of Nigerian societies in precolonial period. This later became widespreadwith the establishment of the colonial rule in Nigeria. In a similar vein, records of British administration and other activities in Nigeria are found in the national archives in Enugu, Ibadan and Kaduna. Such records are also kept in the Public Record Office, London and in other European countries. However, it is important to note that due to thecolonial experience, too much emphasis was placed on the importance of written sources, yet it has some limitations of being corrupted during preservation or be easily lost through destruction by fire.

Therefore, from the foregoing, it is very certain that the writing of history in Nigeria is based on the above sources discuss. It should also be noted that each of the sources has its limitations (Temu and Swai, 1981). In addition, scholars like Dibia and Nwuso (2014), Ojo (2014) and the report of academia (2018) have admitted the fact that all forms of historical sources has their limitations and were often complemented by other form of sources. But the sole task rest on the historian who must make use of this sources in the interpretation and writing of Nigerian history to handle it objectively and professionally.

\section{The Role of Interpretation and Writing of History in Nigeria.}

As already highlighted in the introduction above, the overwhelming task of interpretation and writing of history in Nigeria solely rest on the historians. In other words, the onus of creating historical facts, interpretation of facts and processing the facts in writing or documenting history lies with the Nigerian historians today. Therefore, we shall examine how historical facts are utilize by historian in the reconstruction of Nigerian history. The first critical step a historian would take in the reconstruction of Nigerian history is to obtain his "facts" based on the subject or area being considered. This has informed the assertion made by Carr (1961), that:

..."Not all facts are historical facts. But the distinction between historical and unhistorical facts is not rigid or constant; and any fact may, so to speak, be promoted to the status of a historical fact once it relevance and significance are discerned."

From the statement above, it is the duty of Nigerian historians to carefully examine every fact on a given subject or area based on relevance and significance before such fact is promoted to the status of a historical fact. Historical facts are simply information or evidence about events. In other words, this are affirmations that events occurred. This also means that historical facts are reflections or ideas about actual events which have taken place, and which can no longer be practically felt or observed. Therefore, there is an inseparable link between a historical fact and an event which is why Becker (1955), rightly stated that the actual occurrence and the historical fact, however, closely connected are two different things. Similarly, Akombo (2015), has also emphasize the importance of facts by asserting that "the facts of history do not exist for any historian till he creates them." This is also amplified by Carr (1961), when he remarked that ..." history is the re-enactment inthe historian's mind of the thought of whose history he is studying." 
Volume 4 Issue 15 (December 2021) PP. 89-99 DOI 10.35631/IJHAM.415008

Secondly, it is important also for a historian involved in the writing of history in Nigeria to locate where the facts are. The historical facts may either exist in the historian's mind or in records or documents commonly referred to as sources of history (Akombo 2015). That is one of the reasons for emphasis on sources by historians concerning any subject of study or area in historical scholarship generally. In other words, sources of history are the raw materials from where historians obtained the facts for any historical construction. Therefore, the more the sources, the better it is for the Nigerian historian to effectively discharge his task objectively. This is why Carr (1961), declared that the facts speaks only when the historian calls on them: it is he who decides to which fact to give the floor, and in what order or context. It is very important, to note that it is only after the sources of history is found that the Nigerian historian can begin to call his facts to speak in his preferred order and context.

The third step for a historian to take in the construction or reconstruction of history in Nigeria is the interpretation and selection of facts (Goldstein, 1960). In other words, the historian's purpose determines the type of historical facts he projects, creates or eliminates. This has formed the basis for Carr (1961), submission that history is what the historian makes. In a similar vein, Becker (1955), vividly stated that:

"The purpose the historian has in mind will determinethe precise meaning which he derives from the event. The event itself, thefacts do not say anything, do not impose any meaning. It is the historian who speaks, who impose meaning... The universe speaks to us only in response to our purposes..."

However, the historian does his interpretation and selection of facts based on the criteria of relevance and significance as mentioned earlier. In other words, it is only what the historian considers to be relevant and significance in relation to the subject being studied that he selects as facts or tools to be used for his task of writing history, hence the role of historians in the writing of history in Nigeria. Furthermore, Carr (1961), has also captured the complex task of selection by the historian in these words:

History has been called an enormous jigsaw with a lot of missing parts... Our picture has been preselected and predetermined for us, not so much by accident as by people who were consciously imbued with a particular view and thought the facts which supported the view worth preserving.

From the above statement, the clear reason for this nature of history is the purpose of the historian which exert great influence on his selection process. Because of this inseparable

link Carr (1961), has suggested that the historian should be first studied before the facts, thus: ...the facts of history never come to us 'pure', since they do not and cannot exist in a pure form: they are always refracted through the mind of the recorder. It follows that when we take up a work of history, our first concern should be not with the facts which it contains but with the historian who wrote it... Study the historian before you begin to study the facts.

\section{The Impact of Interpretation and Writing of History in Nigeria.}

Some of the effects interpretation and writing of history is having in Nigeria include: -

First and foremost is the enrichment of our minds with multiple images of events, places, peoples, ideas, and emotions outside our personal experience (Akombo 2015). This is 
Volume 4 Issue 15 (December 2021) PP. 89-99 DOI 10.35631/IJHAM.415008

true because a lot is now known about Nigeria's past which was not the case during the colonial and immediate post independencesperiods. Most importantly, this is motivating younger and more passionate Nigerian historians to make new contributions by writing the histories of their various ethnic nationalities. Similarly, the government of Nigeria and Historical Society of Nigeria (HSN) are encouraging scholars to give more attention to conducting research in Local history.

Another effect is that this influences the life of the community and the course of events. This is common among many ethnic groups in Nigeria. It is so because this is the type of knowledge common men carry around in the head. As such new information from history about each group is rushed at for its presumed value. For instance, the bonds shared by many groups in the past is still upheld today. We can find examples among the Jukuns due to their religio-political control in the past and also by the Fulani and Hausa in northern Nigeria due to the dominance of the Sokoto Jihad in West Africa and present northern Nigeria just to mention a few.

Furthermore, it greatly helps to inevitably picture the past in some fashion and this picture however little correspond to the real past which helps to determine people ideas about politics and society. Frankly speaking, Nigeria has displayed this severally particularly at the regional, continental and in international politics. For instance, Nigeria is among the top African countries that formed the Non-Alignment group during the "Cold War" period between the Eastern and Western Blocks in the 1970s. This could also be seen in its leading role in the creation of regional economic body Economic Community of West African States (ECOWAS) in 1975.

Lastly, it helps to correct the common image of the past by bringing it to test of reliable information. Ojo (2014) rightly notes that it was important to correct some of the errors contained in the early literatures by putting the issues in the proper historical perspective as well as the correctness of the information from the sources consulted. This important step has greatly help in improving the genuineness and quality of historical documentation in Nigeria. For instance, issues like the Eurocentric view and political history of Nigeria has received insight and improved quality. Such similar corrections has equally given fresh insight and indirectly on the interpretation and writing of history by Nigerian historians today.

\section{Conclusion}

It can be seen from the above discourse that the role of interpretation and writing of history in Nigeria is inherently linked to the type of sources available for the writing of Nigerian history. In the same vein, the overwhelming responsibility of getting facts and the interpretation of it and writing of history solely rest on the historian. In other words, the task of interpretation and writing of history in Nigeria rest with the historian for he knows his sources and how to get his facts as well as how to interpret and write or reconstruct the history of Nigeria. In addition, the deployment of the skills of the Nigerian historians in the interpretation and writing or reconstruction of Nigerian's past has greatly thrown more light and better understanding about the history of Nigeria and also improve historical scholarship in Nigeria significantly. 
Volume 4 Issue 15 (December 2021) PP. 89-99 DOI 10.35631/IJHAM.415008

\section{References}

Academia Report (2018) Sources of Nigerian History, https://www.academia.com.ng Retrieved on $18 / 12 / 2021$

Akombo, I. E. (2015). Historical Facts. In S. N. Talla (ed.), Synopses of Some Basic Themes and Concepts in Teaching and Learning History, pp. 78-83, Jalingo, Nigeria, MicronetPublishers.

Andah, B. and Okpoko, A. I. (1979). Oral Tradition and West African Cultural History: A New Direction. Perspectives in West African Past. A special book issue of West African Journal of Archaeology.

Armstrong, R. G. (1960). "The Development of Kingdoms in Negro Africa" in Journal of Historical Society of Nigeria (JHSN), 11, 1960. P. 22.

Becker, L. C. (1955). What are Historical Facts? Atlantic Political Quareterly, Vol. Vill, No. 3.

Carr, E. H. (1961). what is History? Macmillian, London.

Curtin, P. D. (1981) "Recent Trends in African Historiography and their Contribution to History in General" in J. KI-zerbo (ed.), General History of Africa I: Methodology and African Prehistory. P.. 69. Heinemann-Califonia- UNESCO.

Dibia, J.A. and Nwosu, E.O. (2014) Oral Tradition and Historical Reconstruction in Igboland, South East Nigeria. African Journals Online https://www.ajol.info. Retrieved on $18 / 12 / 2021$

Fage, D. J. (1981). “The Development of African Historiography” in J. KI-zerbo (ed.), General History of Africa I: Methodology and African Prehistory, p. 27, University of California Press.

Falola, T. Mahadi, A. Uhomoibhi, M. and Anyanwu, U. (1999). History of Nigeria 1: Nigeria before 1800 AD. PP. Lagos, Longman.

Goldstein, L. J. (1970). "Collingwood's Theory of Historical Knowledge” History and Theory Vol. IX. No I.

Hassan, E. Bala, R. R. and Abubakar, A. (2015). Sources of History. In S. N. Talla (ed) Synopses of Some Basic Themes and Concepts in Teaching and Learning History, pp. 31-35, Jalingo, Nigeria, Micronet Publishers.

Herbst, J. (1968). Theoretical Work in History in American University Curricular' History and Theory Vol. VIII. No III.

Ibrahim, Z. A. (2009). The Significance of Oral Sources in the Reconstruction of Nigeria History in the $20^{\text {th }}$ and $21^{\text {st }}$ Centuries. Zaria Journal of Liberal Arts (ZAJOLA), Vol. 3, no 1. http://www.researchgate-net/publication /29835305. Retrieved on 19/12/2021.

Mohammed, A. Abubakar, A. and Joseph, B. K. (2015). The Place of Oral Tradition in Teaching and Learning History. In S. N. Talla, (ed) Synopses of Some Basic Themes and Concepts in Teaching and Learning History, pp.41-54, Jalingo, Nigeria, Micronet Publishers.

Obiegbu, J. N. (1977). The need for Historiography in the Training of Historians. Tarikh Vol. 5

Ojo, O. E. (2014). A Critique of Some of the Available Secondary Sources on Nigerian History, International Journal of History and Philosophical Research, Vol. 2 no. 1. www.eajournal .org Retrieved on 18/12/2021.

Oladejo, T. M. (2014). History, Research and Documentation in Nigeria: The Relevance to Sustainable Development. Journal of Sustainable Development in Africa, Vol. 16, no. 4. https://jsd-africa.com Retrieved on 19/12/2021. 
Volume 4 Issue 15 (December 2021) PP. 89-99 DOI 10.35631/IJHAM.415008

Stevens, Jr. P. (1978). The Uses of Oral Traditions in the Writing of African History. Tarikh, Smith, R. (ed), pp. 21-30. Longman, London.

Suleiman, S. (2015). The Nigerian History Machine and the Production of Middle Belt Historiography, PhD Thesis, University of Cape Town, South Africa. https://. Open.utc.ac.za/handle/11427/20129, Retrieved on 20/12/2021.

Temu, A. and Swai, B. (1981). Historians and Africanist History: A Critique. Zed Press, London.

Vansina, J. (1985). Oral Tradition as History. Madison, Wisconsin University Press.

Varvar, A. T. (2010). The Relevance of Methodological and Historiographical Courses in the Curriculum of Instruction for History in Tertiary Institutions.

Valerie, R. Y. (2005). Recording Oral History: A guide for Humanities and Social Sciences P. 3. New York, Altamira Press. 